\title{
Article \\ God's Benevolent Love in the Time of COVID-19 Pandemic: Articulations and Experiences of Select Filipino Youth
}

\author{
Rebecca Cacho* and Fides del Castillo (D) \\ Department of Theology and Religious Education, De La Salle University, Manila 1004, Philippines; \\ fides.delcastillo@dlsu.edu.ph \\ * Correspondence: rebecca.cacho@dlsu.edu.ph
}

check for updates

Citation: Cacho, Rebecca, and Fides del Castillo. 2022. God's Benevolent Love in the Time of COVID-19

Pandemic: Articulations and

Experiences of Select Filipino Youth Religions 13: 162. https://doi.org/ 10.3390/rel13020162

Academic Editor: Hans Zollner

Received: 31 December 2021

Accepted: 9 February 2022

Published: 14 February 2022

Publisher's Note: MDPI stays neutral with regard to jurisdictional claims in published maps and institutional affiliations.

Copyright: (C) 2022 by the authors. Licensee MDPI, Basel, Switzerland. This article is an open access article distributed under the terms and conditions of the Creative Commons Attribution (CC BY) license (https:// creativecommons.org/licenses/by/ $4.0 /)$.

\begin{abstract}
Current studies show that the Christian faith is still robust in Philippine society and culture despite the global health crisis. This study investigates how select Filipino Christian youths intuited God's benevolent love in the time of "social distancing" and how their experience of God's benevolence helped them to carry on despite the COVID-19 pandemic. The authors administered open-ended survey questions about God's love to select Filipino Christian youths. The responses were analyzed using thematic analysis and categorizations. Using contextual analysis, the researchers critically reflected upon the respondents' notions of God's love and religious experiences from the two poles of Filipino culture and Judeo-Christian tradition. According to select Filipino Christian youths, God is present and faithful. God's "kagandahang-loob" (benevolent love) for human persons is evinced in the care and kindness of family members and neighbors. God also enables human persons to prevail over challenges in life, such as the COVID-19 pandemic. Moreover, God is the ultimate source of Christian hope. This hope is firmly anchored in Jesus Christ and the Church. Furthermore, God is forgiving and merciful. He continues to bless and give graces to human persons despite their sinfulness. These contemporary conceptualizations of God's perfect interior goodness helped the select Filipino Christian youths cope with the COVID-19 pandemic.
\end{abstract}

Keywords: faith; religion; youth study; cultural analysis; benevolent love or kagandahang-loob; religious coping; contextualization; COVID-19 pandemic; suffering; loving God

\section{Introduction}

Current academic studies revealed that there is a significant relationship between context, religion, and the COVID-19 pandemic (Hammer and Swartz 2021). A study among select countries from the Global North (where secularization is rapidly growing) showed that the COVID-19 outbreak has bolstered the religious faith of some people (Pew Research Center 2021). Yet, this phenomenon remains to be seen among countries in the Global South. As such, this article contributes to the discussion by providing a local case study from the Philippines.

The Philippines is a predominantly Christian country. Around $80 \%$ of Filipinos are Roman Catholics, and 8\% belong to other Christian denominations (Philippine Statistics Authority 2019). Macaraan (2019) asserts that "[many] Filipinos' sociocultural normative and lifeworld is deeply imbued with Catholic cosmologies and expressions" (p. 106). In one of his pastoral visits to the Philippines, John Paul II (1981) declared, "The rich geographical and human diversity, the various cultural traditions, and the people's spirit of joy and sharing, together with the fruits of the missionary efforts, have successfully blended and have shaped, through periods which were sometimes not devoid of shadows and weaknesses, a clear national identity that is unmistakably Filipino and truly Christian" (p. 2).

Among the estimated 100 million Filipinos, 28\% are youths aged 10 to 24 years (UNFPA Philippines 2020). Current studies on the religiosity of Filipino youths by del Castillo et al. (2021) revealed that many Filipino Christian youths are not "nominal Christians" but 
religious. They "have a profound religious life, and the Christian faith plays a central role in their life" (p. 10). Moreover, del Castillo and Alino (2020) discovered that many Filipino Catholic youths employ a pattern of positive religious coping. During difficult times, they "ask God for the forgiveness of sins", "try to see how God might be trying to strengthen them in the situation", "seek for God's love and care", and "look for a stronger connection with God" (p. 10).

The Philippines has suffered the world's longest COVID-19 related lockdown (Guido 2021). To a certain extent, the prolonged community quarantine contributed to the nation's bottom ranking in the list of COVID-19 resilient countries (Calonzo 2021). Moreover, the mobility restrictions and social distancing implemented by the Philippine government have significantly altered the country's religious landscape (Agence France-Presse 2020). Despite this, many Filipino Christians assert that faith in God is vital in the fight against COVID-19 (Patinio 2020). During difficult times, numerous Filipino Christians have found comfort in the abiding presence of the divine, have asked for God's help (Rilveria 2018), and collaborated with God in problem-solving (del Castillo and Alino 2020).

God is "pure positivity" (Schillebeeckx 1980) whose unconditional love and benevolent kindness are at the heart of the divine intent towards a quality life for humankind and the rest of creation (cf. John 3:16). This unconditional, gracious, and winsome love of God was fully and definitively fulfilled in Jesus of Nazareth (cf. Col. 1:15). Such is the singular expression that ascertains a dependable God whose love for humanity is true and wills only the fullness of life for all (cf. John 10:10); however, such articulations of faith were put to the test during the COVID-19 pandemic. As of this writing, the virulent disease has taken more than 5.3 million lives worldwide (WHO Coronavirus (COVID-19) Dashboard 2021). The emergence of SARS-CoV-2 variants, the rising number of COVID-19 infections (COVID-19 Data Explorer 2021), and the long-term health and societal impacts of COVID-19 (Saladino et al. 2020) had detrimental effects on the mental (Kumaravel et al. 2020), physical well-being (Mattioli et al. 2020), and spiritual health (del Castillo 2020) of many people.

\section{Objectives of the Study}

Kagandahang-loob is a concept which implies all that is good in a person and, as such, is ideal for Filipinos; it connotes pure positivity experienced in one's relationships with others. Since this is a quintessential value, it is accorded to a person only after time-tested kindness and authentic acts of goodness have been observed (de Mesa and Cacho 2017). Instead of translating God is love to Diyos ay pag-ibig, which is the conventional expression of the phrase in the Christian churches, the paper proposes that the articulation, Diyos ng kagandahang-loob, is a more dynamic equivalent of the said faith statement because it does not only highlight the agapeic character of God's benevolent love but it also brings to the fore the cultural underpinnings of the concept which are more intelligible and meaningful to lowland Filipinos.

Likewise, we hope to explore how faith in a loving God (Diyos ng kagandahang-loob) affected people's coping skills in facing the negative repercussions of the pandemic. In this way, we intend to contribute to the ongoing reflections and knowledge achieved by analyzing the impact of faith in God on the overall health and wellness of young people. Providing space for the faith perspectives that communicate how human resilience and convictions in God's kagandahang-loob (benevolently loving God) were sustained may offer insights on how negative occurrences could in reality pave the way for renewed passion or commitment to promoting quality life for all.

Against the background presented above, this paper takes a closer look at the selected Filipino youth's perspectives on God as kagandahang-loob (God is love) based on their experiences during the pandemic. In particular, it hopes to answer the following questions:

1. How is God's kagandahang-loob (benevolent love) understood and experienced within the cultural context of selected Filipino youth? 
2. How are the perspectives of selected Filipino youth resonate with the characteristics of kagandahang-loob based on the cultural analysis made?

3. What are the implications of God's kagandahang-loob for the faith-life of selected Filipino youth during the COVID-19 pandemic?

It is noticeable that there are emerging perspectives on how young people cope with the pandemic and its negative implications for human well-being. Research works, reflections, and correspondences are mostly focused on this phenomenon. While medical, psychosocial, economic, and political initiatives proliferated, the religious perspectives and faith narratives of young people may also shed light on this issue. Likewise, to clarify the concept of kagandahang-loob (benevolent love), a cultural analysis will be presented to highlight its potential to re-interpret an aspect of Christian faith and understand the current human experiences through the lens of the culture of Filipinos.

\section{Review of Related Literature}

\subsection{Religious Coping during the Pandemic}

When people are confronted by crisis or debilitating situations such as the present pandemic, they turn to different coping mechanisms to manage stress and difficulties. In the study conducted by Fatima et al. (2020) among selected respondents in India and Nigeria, it was found that a significant number of people made use of religious measures to overcome the difficulties brought about by COVID-19. Likewise, the study of del Castillo and Alino (2020) indicated that many Filipino Catholic youth used positive religious coping methods more frequently than negative strategies. This means that positive religious activities among people were preferred as a means to solve the problems they encountered. Turning to God for strength, hope, and consolation with faith in divine benevolence instead of getting angry with God was noted to provide better means of coping with stress or counter depression. In a similar study conducted by Zarrouq et al. (2021), it was noted that Moroccan patients who became depressed and anxious during the pandemic made use of religious coping mechanisms to help them overcome fear, loneliness, and anxiety. This validated the "widespread belief that religiosity provides a source of attitudes that can reframe negative events into less stressful frames" (Zarrouq et al. 2021).

Among the healthcare workers in Portugal, Prazeres et al. (2020) concluded that the "delivery of out-of-hours online religious and spiritual support for healthcare workers may be a viable solution" (p. 9) to help them cope with their fears of COVID-19. It was noted that stronger expressions of support from their significant relationships provided them psychological strength and a resilient attitude, especially when they dealt with their COVID-19 patients. The study found out that a number of factors derived from the pandemic and psychosocial factors like gender, financial constraints, fear of being infected, constant exposure to bad news about COVID-19, and use of negative religious coping, were associated with a greater risk of depression and worsening the anxiety of people.

In similar research done by Thomas and Barbato (2020), it was found that Muslims who showed less dependence on religious coping during the pandemic manifested high levels of depression which exacerbated their previous psychological disorder. It was also noted that "a younger age and less reliance on religious coping were associated with poorer mental health" (Thomas and Barbato 2020). While the study compared how Christians and Muslims in Saudi Arabia were helped by positive religious coping during the pandemic, the results showed that the Muslims were more reliant on religious coping mechanisms to lower depression tendencies. This was attributed to the restrictions implemented against Christian services in a country where the majority religion is Islam.

\subsection{God's Benevolent Love}

Love is at the core of the Christian Faith. Jesus Christ summoned his disciples to love one another in the same way he loved them (cf. John 13:34); he further reiterated that it is through love that true discipleship may be realized or singularly recognized. Love is the mark of a faithful Christian (cf. John 13:35). Biblical perspectives on God highlight the 
same theme as gleaned from the Old Testament (cf. Nehemiah 9:17; Isaiah 43:1-3; Isaiah 54:10) and the New Testament passages (cf. 1 John 4:7-8; Romans 8:37-39; Ephesians 2:4-5). The collective Christian experience of God in Jesus Christ is summed up in the affirmation that "God is love" (cf. 1 John 4:8,16). The invisible love of God became visible in Jesus Christ (cf. 1:15) who went around doing good (cf. Acts 10:38; Mark 7:37). As such, when the Christian Tradition talks about the active providential love of God, it necessarily sets its sight on Jesus and regards him as "the shepherd with a beautiful self" (cf. John 10:11).

Current studies show that God's benevolent love is relevant in these contemporary times. First, there is a significant link between a person's positive image of God and finding purpose in life. Stroope et al. (2013) assert that for some people, the notion of a loving God facilitates a hope-filled vision of life despite difficult situations. Second, religious experiences such as feeling the loving presence of God can help a person prevail over a certain level of discontent. Zahl and Gibson (2012) note that for some Christians, positive "experiential God representations are more meaningful than doctrinal God representations" (p. 219). Such positive religious experiences contribute to a person's satisfaction with life. Third, the belief in a God who cares for human persons strengthens the marital bond and quality of parenting for some Christian couples. Moore et al. (2018) claim that the Scripture and prayers assure Christian believers that God intimately cares for human persons. This belief positively shapes how some Christian couples approach family relationships. Fourth, select young people who subscribe to a loving image of God usually exhibit positive behavior. Shepperd et al. (2019) discovered that for some adolescents, "emphasizing a loving God may be an effective means of encouraging desirable behavior" (p. 400). Fifth, religious engagements that originate from a positive image of God can contribute to better regard for self and foster life-giving relationships. Schieman et al. (2017) claim that religious faith anchored in a supportive and loving God helps develop self-esteem. Lastly, belief in God's benevolence helps create positive emotions and leads to positive behaviors for some people. Exline et al. (2017) note that when "people see God as all-powerful but benevolent in intention toward people (e.g., suffers with us; intends suffering for our growth; helps us to overcome suffering), such beliefs could foster positive thoughts, feelings, and behaviors involving God" (p. 507).

\subsection{Exposition of the Vernacular Term "Maganda" (Beautiful)}

The root word of the Filipino term "maganda" is "ganda" which means beauty. Many Filipinos gravitate towards what is beautiful and seek it (Tan 2007). The Filipino term maganda is often used in local talk to refer to people, objects, or events that are attractive, elegant, and pleasing, among others. Maganda is used by Filipinos to describe the general experience of harmony in life when everything seems to be in order (Almario 2010).

For many Filipinos, people who are inherently kind and generous are deemed to possess "magandang kalooban" (i.e., a beautiful person on the inside) (de Mesa and Cacho 2017). Deeper human realities can also be assessed as to whether they are maganda or not; for example, relationships are maganda when people relate with sincerity and reliability. The same can be said when kindness is spontaneously extended, or when individuals join hands to accomplish a common task regarded as important. When Filipinos are positively touched by behavior or events, they refer to them as maganda. They evaluate what they see and observe as well as weigh the import of their experiences as a whole by judging them as maganda or hindi maganda (ugly, bad, unpleasant), thereby suggesting that this value is used as norm or standard by Filipinos (Padilla 2017). Based on these considerations, the term maganda stands for a delight-bringing "totality". Jocano (2001) notes, maganda is "not a mere aspect of a social, intellectual, and material reality but the total of katangian (traits) associated with anything" (pp. 135-36). This is why Filipinos consider pleasant physical appearance as insufficient in what they would call maganda if there is no corresponding goodness in character. Hence, the term maganda exhibits both breadth and depth. It can characterize the whole of life, relationships, a person's being and disposition, the natural environment, or any object of admiration (English 1986). 
Three ethical expressions of maganda can be highlighted for a holistic understanding of this indigenous concept. First, "maganda ang mabuti" (there is beauty in gracious goodness). This refers to the winsome goodness intended for genuine beneficence or well-being of people (de Mesa and Cacho 2017). The kind of goodness shown stems from the goodness of one's heart and a pure desire to extend kindness to another. Second, "maganda ang maayos" (there is beauty in orderliness) implies harmony and proper ordering or organization of things and relationships in society (Miranda 1992). It includes the Filipino concepts of "maaliwalas" (spaciousness) and "maayos na samahan" (congenial relationships) which are highly desirable for many Filipinos (Padilla 2017). As such, the Acts and Decrees of the Second Plenary Council of the Philippines (1992) articulated that "[ ... ] in the depths of the Filipino spirit is a longing for kaayusan [order] out of chaos [ ... ]" (PCP II, \# 257). Third, "maganda ang totoo at walang daya" (there is beauty in truth and guilelessness). This refers to all "that is true, real and without a cover-up" (de Mesa and Cacho 2017, p. 22). Therefore, for beauty to be real, there must be authenticity without any hint of hidden agenda or selfish gain for extending kindness to another person. Maganda, as a value, challenges people's truthfulness and integrity.

\section{4. "Kagandahan-Loob"-Agapeic Character of God's Benevolent Love}

The Filipino term maganda implies anything that charms, edifies, and brings delight. This finds resonance to what the French philosopher Jacques Maritain (2010) expressed on the impact of beauty: "a delight which superabounds and overflows" (p. 30); de Castro (1999a) notes that maganda may be regarded as "a central concept in Philippine ethical discourse because it is a basic component of morally worthy behavior" (p. 39). Besides this usage, however, maganda also implies the authentic relational goodness of a person coupled with what is ethically good. As such, de Mesa and Cacho (2017) asserts that maganda calls our attention to the beauty that is found in our deepest and "most authentic relational self, ang kagandahan ng loob [or] the beauty within" (p. 24).

Many Filipinos are aware that to speak of the vernacular term loob (the most authentic relational self) is to converse about their most genuine relational self whence feelings, thoughts, and behaviors are found and proceed towards (Alejo 1990). To talk about the beauty within the realm of the loob, then, is to refer to the beauty that is not only genuine but relational. As loob is the relational self of Filipinos, what is found in the truest and deepest self is discoverable only in relationships with God, with fellow humans, and with the rest of creation (de Mesa and Cacho 2017). It may also be understood as a "symbolic interior" which is at the "core" of humanity (Miranda 1992).

In terms of what is yearned for and the highest standard of one's being, kagandahangloob (beauty within) is "the quintessential Filipino value" (Miranda 1992, p. 182). For many Filipinos, there is no greater beauty than kagandahang-loob. It is the paramount value and, when attributed to a person, it is the most supreme compliment. No greater honor can be given to a person in the Filipino context than to be regarded as a person whose loob is truly maganda. de Mesa and Cacho (2017) said, "ganda is beauty with a touch of charm; it combines true goodness and heartwarming allure. The maganda is an interweaving of what is ethically and aesthetically positive. It is our term for what is deemed ethically good" (p. 25). Moreover, kagandahang-loob is winsome goodness since it combines ethical goodness and aesthetic charm. It is untainted goodness or "pure positivity" (Schillebeeckx 1980) that captivates and wins people over. Hence, relating kagandahang-loob to God is a more dynamic faith statement because it highlights the agapeic character of God's benevolent love. It shows the cultural underpinnings of the concept which are more meaningful to Filipinos.

As such, "God is love" which is conventionally expressed in the Filipino vernacular as "Diyos ay pag-ibig" is dynamically translated in this paper as "Diyos ng kagandahangloob". It brings to the fore the salvific value of God's love, which transforms, heals, and comforts those who suffer (cf. Isaiah 38:17; Luke 6:19; Matthew 11:28-30; 2 Corinthians 1:3; Jeremiah 17:14). 


\section{Methodology}

God's love sustains a culture of life, brings hope and wholeness to believers despite periods of trial and tribulation. As such, this paper's methodological process is countercultural since it explicitly opposes the culture of death, messages of hopelessness, and feelings of brokenness brought by the COVID-19 pandemic.

Using a descriptive research design, this study investigates how "kagandahang-loob ng Diyos" (God's love) is conceptualized and experienced by select Filipino Christian youths during the global health crisis. Creswell and Creswell (2018) assert that a descriptive research design involving five to 25 respondents as sample size can shed light on current trends, attitudes, or opinions in a given population.

Informed by the research theories on lived religious experiences and gleaning from current studies on God's love and youth religiosity, the researchers asked two open-ended survey questions to unpack "kagandahang-loob ng Diyos" among a group of Filipino Christian youths during the global health crisis. The questions are:

1. How will you describe God's love?

2. How did you experience God's love during the COVID-19 pandemic?

Convenience sampling was adopted in the present study. A total of 24 Filipino youth aged 18-22 years old participated. The respondents were all Christians. The answers to the open-ended survey questions were analyzed using thematic analysis and categorizations. The survey questions were administered online through Google forms. After answering the informed consent and the required demographics, the respondents answered the survey. The only personal data collected from the respondents were religious affiliation, age, and gender.

The responses of the select Filipino Christian youths were analyzed using thematic analysis and categorizations. The researchers gleaned the first-order constructs from the texts and then synthesized them into second-order constructs. Using contextual theology, the researchers critically reflected upon the second-order constructs from the two poles of Filipino culture and Judeo-Christian tradition.

The cultural analysis of kagandahang-loob involved a hermeneutic of appreciation. The study followed the following principles: (1) assumption of a given perspective, (2) awareness of one's cultural presuppositions, (3) use of the insider's point of view, (4) going beyond the cultural stereotypes, and (5) use of vernacular as a key to understanding the culture (de Mesa 2016). The narratives or verbatim remarks subjected to a hermeneutics of appreciation revealed the themes of kagandahang-loob experienced by the respondents (Resurreccion 2007).

\section{Results}

\subsection{Notions of God's Love by Select Filipino Christian Youths}

Table 1 shows the notions of God's love by select Filipino Christian youths. The majority of the female respondents said that God's love is faithful. A respondent wrote, "God is present in every moment of my life and continues to be in every experience, no matter how small or seemingly insignificant it may be". Many of the male respondents conceptualize God's love as kind and caring. An interlocutor said, "I feel God's soothing kindness and care". Moreover, God's love is a source of hope; a male respondent wrote, "God can heal and give me hope and a future". Lastly, God, who is love, is merciful and forgiving. One female respondent said, "My savior has ransomed me and showed how forgiving and merciful God is regardless of the sins I have committed". 
Table 1. Notions of God's love by select Filipino Christian youths.

\begin{tabular}{ccccc}
\hline Notions & Male & Female & Frequency & $\%$ \\
\hline Present and faithful & 1 & 8 & 9 & $37.50 \%$ \\
Kind and caring & 8 & 1 & 9 & $37.50 \%$ \\
Source of hope & 3 & 1 & 4 & $16.67 \%$ \\
Forgiving and merciful & 1 & 1 & 2 & $8.33 \%$ \\
Total & 13 & 11 & 24 & $100.00 \%$ \\
\hline
\end{tabular}

\subsection{Experiences of God's Love by Select Filipino Christian Youths during the COVID-19 Pandemic}

Table 2 shows how select Filipino Christian youths experienced God's love during the COVID-19 pandemic. The majority of the respondents reported that they experienced God's benevolent love during the global health crisis through the care of their family and neighbors. One respondent wrote, "I was able to feel God's love and presence through my family members. My dad and grandma are both very religious people, and every night I can see my dad pray for me and my family before he goes to bed". Interestingly, some Filipino Christian youths discovered and felt God's presence in "pagsubok sa buhay" or trying times. An interlocutor said, "I was at the lowest point of my life because I had just cut off ties with one of my closest friends. I was so lost in my ways that I would engage in vice and have a negative outlook towards life; however, God's love met me there, all the way through my struggles". Further, all the female interlocutors in this study believe that God's benevolent love is made palpable by Jesus Christ and the Church. One respondent said, "I deeply feel God's presence in my life through Jesus Christ". Another one wrote, "I feel God's love when I am praying or in church". Lastly, despite the many challenges brought by the global health crisis, there are Filipino Christian youths who acknowledged God's benevolence through the many "biyaya" or blessings that they have received. As one respondent attested, "I find myself reflecting and contemplating on the blessings that I received, and I feel the love of the Lord".

Table 2. Experiences of God's Love By Select Filipino Christian Youths During the COVID-19 Pandemic.

\begin{tabular}{ccccc}
\hline Concepts & Male & Female & Frequency & $\%$ \\
\hline $\begin{array}{c}\text { God's love is evinced by family } \\
\text { and neighbors }\end{array}$ & 7 & 3 & 10 & $40.74 \%$ \\
\hline $\begin{array}{c}\text { God is with us during life's } \\
\text { challenges }\end{array}$ & 5 & 3 & 8 & $33.33 \%$ \\
\hline $\begin{array}{c}\text { God's benevolent love is made } \\
\text { palpable by Jesus Christ and the } \\
\text { Church }\end{array}$ & 0 & 4 & 4 & $15.81 \%$ \\
\hline $\begin{array}{c}\text { God, who is love, gives us } \\
\text { blessings in life }\end{array}$ & 1 & 1 & 2 & $10.11 \%$ \\
\hline Total & 13 & 11 & 24 & $100.00 \%$ \\
\hline
\end{tabular}

\section{Discussion}

5.1. Cultural Analysis of Kagandahang-Loob vis-à-vis the Notions and Experience of God's Love by Select Filipino Christian Youths

The dogmatic form of analysis is the most common way of understanding the Christian faith in the Philippines. Anchored on indoctrination-albeit using foreign concepts-it is the form of evangelization that has been popularized by missionaries from the West (Bevans 2003). Instead of using the lens of culture in understanding present experiences or the prevailing phenomenon, cultural analysis was relegated to the fringes of theological discourses because it was believed to be ineffective in addressing social ills (de Mesa 2016). It was through the Synod of Synod of Bishops (1974) and Pope Paul VI's (1975) Evangelii Nuntiandi that cultural analysis was retrieved and recognized as central to the task of 
evangelization. In understanding the current experiences of believers, the cultural context is necessary, but this does not discount the wisdom which could be derived from the Faith Tradition they embraced. Mutual interaction between these two poles would render a more contextualized theological reflection that is intelligible to the present generation of Christians. In particular, the specific anthropological approach being employed highlights the positive and life-giving elements of the cultural experiences which may engender more meaningful and relevant reflections on how faith in a loving God (which is central to Christian Tradition) nurtures and sustains the Filipino youth as they grapple with the challenges posed by the COVID-19 pandemic.

\subsection{Qualities of Kagandahang-Loob (Benevolent Love)}

Kagandahang-loob may be gauged for its authenticity through time and space. Constancy and repetition over time could validate the genuineness of such quality in a person: de Mesa (2016) asserts, "The truth about the loob cannot be discovered in an instant. A reasonable length of time is required to ascertain if the loob of the other we are probing into is beautiful or ugly, good or bad" (p. 307). While initial experiences of another person's goodness signal their kagandahang-loob, only time and changing situations may attest to the truthfulness of this quality, which may be inherent in a person. The study of Resurreccion (2007) on kagandahang-loob among select Filipinos categorized the important value into three domains: (1) malasakit (compassion), (2) pakikipagkapwa (shared humanity), and (3) malinis na kalooban (genuine goodness of one's person). Thus, kagandahang-loob implies all that is authentically virtuous in a person.

The results of the current study align with the findings of Resurreccion (2007); however, the new contribution of this paper is that its respondents are dealing with an unprecedented global health crisis. As such, the interlocutors in this study articulated other cognates of the concept. For select Filipino Christian youths, God's love-kagandahang-loob—is present and faithful, kind and caring, forgiving and merciful, and a source of hope. These qualities describe a God of pure positivity. Such positive beliefs can increase positive emotions and help reduce emotional disorders (Koenig 2012). This is important during trying times like the COVID-19 pandemic. Moreover, the notions of God's love by some Filipino Christian youths reveal that they somewhat practice "religious coping". Pargament et al. (2011) mentioned that "positive religious coping methods reflect a secure relationship with a transcendent force, a sense of spiritual connectedness with others, and a benevolent world view".

\subsection{Experiences of Kagandahang-Loob ng Diyos (God's Benevolent Love)}

First, the select Filipino youth view of God's kagandahang-loob is perceived as an eminently relational experience. They see, feel and experience God's benevolent love in their family, neighbors, Jesus Christ, and the Church. People may only be known to possess kagandahang-loob through their relationship with others. It cannot be experienced apart from fellow human beings but is demonstrated through loving-kindness extended to others (de Castro 1999a). Second, kagandahang-loob originates from the personal initiative of the one acting. An act of kagandahang-loob is graciously free (Resurreccion 2007). Forced or manipulated kagandahang-loob is not authentic. The Filipino expression "bukal sa kalooban" (welling up from the most authentic inner self) suggests that the kagandahang-loob being manifested is truly in harmony with the most authentic in the person, and could be likened to spring from an unadulterated and pure source (de Mesa and Cacho 2017). Third, kagandahang-loob is directed towards the well-being of the other. It is intended for the person to flourish humanly and attain a quality life. Because it is not self-oriented, it has the other in mind rather than the self. "A deed lacks nobility if it is motivated by self-interest and not by a sincere desire to help. Hence, actions calculated to derive public recognition or material reward do not have the purity that is essential to kagandahang-loob even if they are truly beneficial to others" (de Castro 1999b, p. 39). The person who is the "object" of kagandahang-loob is related to and dealt with as a person worthy of respect. Because of 
this other-directedness of kagandahang-loob, it does not seek for anything in return in the concerned reaching out towards that other. Any manifestation of kagandahang-loob which is ultimately based on a do ut des (Latin for "I give so that you will give") mentality falsifies its real meaning (de Mesa 2016). Fifth, kagandahang-loob is not self-seeking and does not look for a "return of the favor". As a quality of a person, kagandahang-loob is also characterized by its tendency to what may easily be construed as an "excessive" manifestation of goodness and generosity. The kagandahang-loob shown goes beyond the usual limits of necessity, duty, or sufficiency and may even go further than what is specified or expected, considered proper or just (de Mesa and Cacho 2017).

Many people rely on religious beliefs, and practices to cope with life's difficulties, challenges, and stressors (Abu-Raiya and Pargament 2015). Exline et al. (2017) observed that difficult circumstances can deepen a person's faith in a benevolent God. For some Filipino Christian youths, it is in these challenging times that they have come to realize the kagandahang-loob of God. Moreover, some Filipino Christian youths interpreted God's blessings as expressions of his benevolent love during the COVID-19 pandemic. This agrees with the teachings of the Catholic Church. Pope Francis (2016) said that God's love is boundless and that we could get a glimpse of this in the many blessings that we receive in life. A benevolently loving God wills only the happiness of human persons and the experience of the fullness of life offered freely in Christ (cf. John 10:10).

\section{Strengths and Limitations}

This study of contemporary notions and experiences of God's benevolent love by select Filipino Christian youths during the time of COVID-19 pandemic provides some evidence on how an essential Christian doctrine helped some people to cope with the global health crisis.

More importantly, this paper takes into account the Filipino context to provide an academic explanation of God's benevolent love, "our refuge and strength, a very present help in trouble" (cf. Ps 46:1). Privileging the Filipino cultural voice (de Mesa 2018), the researchers put forward "kagandahang-loob ng Diyos" as the indigenous appellation for "God's benevolent love". Kagandahang-loob in Filipino culture is inextricably linked with saving presence, faithfulness, acts of kindness, and human compassion. As such, kagandahang-loob profoundly expresses the salvific character of God's benevolent love.

Admittedly, the number of respondents in this study is limited. It brings to the fore the voices of select Filipino Christian youths who struggled with the challenges brought by the COVID-19 pandemic. Moreover, it highlights a particular indigenous conceptkagandahang-loob - to re-cast God's benevolent love. As such, the results in this paper cannot be generalized for all Christians. However, a study can be pursued by other researchers using a larger sample to investigate how Christian beliefs support the overall sense of well-being of adherents struggling with a major life stressor.

\section{Conclusions}

This study showed how God's kagandahang-loob was understood and experienced within the cultural context of select Filipino Christian youths. God is present and faithful. God's "kagandahang-loob" (interior goodness) for human persons is evinced in the care and kindness of family members and neighbors. God also enables human persons to prevail over challenges in life such as the COVID-19 pandemic. Moreover, God is the ultimate source of Christian hope. This hope is firmly anchored in Jesus Christ and the Church. Furthermore, God is forgiving and merciful. He continues to bless and give graces to human persons despite their sinfulness. These contemporary conceptualizations of God's perfect interior goodness helped the select Filipino Christian youths cope with the COVID-19 pandemic. 


\begin{abstract}
Author Contributions: Conceptualization, R.C. and F.d.C.; methodology, F.d.C.; validation, R.C. and F.d.C.; formal analysis R.C. and F.d.C.; investigation, R.C. and F.d.C.; resources, R.C. and F.d.C.; data curation, R.C.; writing —original draft preparation, R.C. and F.d.C.; writing-review and editing, R.C. and F.d.C.; visualization, R.C. and F.d.C.; supervision, R.C. and F.d.C.; project administration, R.C. and F.d.C. All authors have read and agreed to the published version of the manuscript.
\end{abstract}

Funding: This research received no external funding.

Institutional Review Board Statement: The study was conducted per the guidelines of the Declaration of Helsinki. Data were collected within an accepted educational setting. More importantly, the information obtained is encoded in such a manner that the identity of the human subjects cannot readily be ascertained, directly or through identifiers linked to the subjects.

Informed Consent Statement: Informed consent was obtained from all subjects involved in the study.

Data Availability Statement: Data for the current study is available upon written request to the corresponding author.

Acknowledgments: The authors are deeply grateful to De La Salle University Manila, Jose de Mesa and Clarence Darro del Castillo.

Conflicts of Interest: The authors declare no conflict of interest.

\title{
References
}

Abu-Raiya, Hisham, and Kenneth I. Pargament. 2015. Religious coping among diverse religions: Commonalities and divergences. Journal of Psychology and Theology 43: 148. [CrossRef]

Acts and Decrees of the Second Plenary Council of the Philippines. 1992. Acts and Decrees of the Second Plenary Council of the Philippines. Manila: Catholic Bishops' Conference of the Philippines.

Agence France-Presse. 2020. Lockdown Tests Faith in Virus-Hit Philippines. Available online: https://newsinfo.inquirer.net/1346004/ lockdown-tests-faith-in-virus-hit-philippines (accessed on 29 December 2021).

Alejo, Albert. 1990. Tao po!: Tuloy! Isang landas ng pang-unawa sa loob ng tao. Quezon City: Office of Research and Publications of Ateneo de Manila University.

Almario, Virgilio, ed. 2010. UP diksiyonaryong Filipino: Binagong edisyon. Quezon City: UP sentro ng wikang Filipino.

Bevans, Stephen. 2003. Unraveling a "Complex Reality": Six Elements of Mission. International Bulletin of Missionary Research. Available online: http:/ / www.internationalbulletin.org/issues/2003-02/2003-02-050-bevans.pdf (accessed on 1 December 2021).

Calonzo, Andreo. 2021. Philippines Still Worst Place in Covid Even es Cases Ease. Available online: https://www.bloomberg.com/ news/articles/2021-10-27/ philippines-still-worst-place-in-covid-even-as-cases-ease-off (accessed on 29 December 2021).

COVID-19 Data Explorer. 2021. COVID-19 Data Explorer. Our World in Data. Available online: https://ourworldindata.org/explorers/ coronavirus-data-explorer?zoomToSelection=true\&time=2020-03-01..latest\&facet=none\&pickerSort=desc\&pickerMetric=new cases_smoothed_per_million\&Metric=Confirmed+cases\&Interval=7-day+rolling +average\&Relative+to + Population $=$ true $\&$ Align+outbreaks=false\&country=IND $\sim\{U S A \sim\{\}$ GBR $\sim\{C A N \sim\{\} D E U \sim\{\} F R A$ (accessed on 26 December 2021).

Creswell, John, and David Creswell. 2018. Research Design: Qualitative, Quantitative, and Mixed Methods Approaches, 5th ed. Thousand Oaks: SAGE Publication.

de Castro, Leonardo. 1999a. Critical care in the Philippines: The "Robin Hood Principle" vs. Kagandahang loob. In National Library of Medicine. Available online: https:/ / pubmed.ncbi.nlm.nih.gov/10190841/ (accessed on 19 June 2021).

de Castro, Leonardo. 1999b. Kagandahang loob: Love in Philippine bioethics. Eubios Journal of Asian and International Bioethics 9: 39-40. Available online: https:/ / www.eubios.info/EJ92/ej92e.htm (accessed on 18 June 2021).

de Mesa, Jose. 2016. Jose M. de Mesa: A Theological Reader. Manila: De La Salle University Publishing House.

de Mesa, Jose. 2018. Contextual Theology from a Cultural Perspective. In Christian Mission, Contextual Theology, Prophetic Dialogue: Essays in Honor of Stephen B. Bevans, SVD. Edited by Dale T. Irvin and Peter C. Phan. Maryknoll: Orbis Books.

de Mesa, Jose, and Rebecca Cacho. 2017. In Love with God: Doing Theology for Students. Quezon City: C\&E Publishing Inc.

del Castillo, Fides. 2020. Health, spirituality and Covid-19: Themes and insights. Journal of Public Health 43: e254-e255. [CrossRef] [PubMed]

del Castillo, Fides, and Marie Antoinette Alino. 2020. Religious Coping of Selected Filipino Catholic Youth. Religions 11: 462. [CrossRef]

del Castillo, Fides, Clarence Darro del Castillo, Gregory Ching, Michael Ackert, Marie Antoinette Aliño, and Rene Nob. 2021. Validation of the Abrahamic Forms of the Centrality of Religiosity Scale (CRS-5, CRS-10, and CRS-15): Evidence from Selected University Students in the Philippines. Religions 12: 84. [CrossRef]

English, Leo James. 1986. Tagalog-English Dictionary. Pasay City: Congregation of the Most Holy Redeemer.

Exline, Julie J., Todd W. Hall, Kenneth I. Pargament, and Valencia A. Harriott. 2017. Predictors of growth from spiritual struggle among Christian undergraduates: Religious coping and perceptions of helpful action by God are both important. The Journal of Positive Psychology 12: 501-8. [CrossRef] 
Francis. 2016. Jubilee Audience of 10 September 2016: Mercy And RedemptionFrancis. Rome: Libreria Editrice Vaticana. Available online: https:/ / www.vatican.va/content/francesco/en/audiences/2016/documents/papa-francesco_20160910_udienza-giubilare. html (accessed on 20 December 2021).

Guido, Edison. 2021. How the Philippines Can Recover From One of the World's Longest Lockdowns. Available online: https: / /jia.sipa.columbia.edu/online-articles/how-philippines-can-recover-one-world\%E2\%80\%99s-longest-lockdowns (accessed on 29 December 2021).

Hammer, Olav, and Karen Swartz. 2021. Vol. 11 No. 2 (2021): Religious Responses to the COVID-19 Pandemic. Available online: https:/ /journal.fi/ar/issue/view/7925 (accessed on 29 December 2021).

Fatima, Huma, Tosin Philip Oyetunji, Sudha Mishra, Krittika Sinha, Olorunyomi Felix Olorunsogbon, Oluwayemi Samson Akande, Srinivasan, and Sujita Kumar Kar. 2020. Religious coping in the time of COVID-19 Pandemic in India and Nigeria: Finding of a cross-national community survey. International Journal of Social Psychiatry. [CrossRef]

Jocano, Landa. 2001. Filipino Worldview: Ethnography of Local Knowledge. Manila: Punlad Research House Inc.

John Paul II. 1981. Message to the President and to the People of the Philippines. Available online: https://www.vatican.va/ content/john-paul-ii/en/speeches/1981/february/documents/hf_jp-ii_spe_19810217_manila-presidente.pdf (accessed on 26 December 2021).

Koenig, Harold. 2012. Religion, Spirituality, and Health: The Research and Clinical Implications. ISRN Psychiatry 2012: 278730. [CrossRef]

Kumaravel, Santhosh Kumar, Ranjith Kumar Subramani, Tharun Kumar Jayaraj Sivakumar, Rajvikram Madurai Elavarasan, Ajayragavan Manavalanagar Vetrichelvan, Annapurma Annam, and Umashankar Subramaniam. 2020. Investigation on the impacts of COVID-19 quarantine on society and environment: Preventive measures and supportive technologies. 3 Biotech 10: 393. [CrossRef]

Macaraan, Willard. 2019. A kapwa-infused paradigm in teaching Catholic theology/catechesis in a multireligious classroom in the Philippines. Teaching Theology and Religion 22: 102-13. [CrossRef]

Maritain, Jacques. 2010. Art and Beauty. Available online: https://maritain.nd.edu/jmc/etext/art5.htm (accessed on 1 December 2021).

Mattioli, Anna Vittoria, Matteo Ballerini Puviani, Milena Nasi, and Alberto Farinetti. 2020. COVID-19 pandemic: The effects of quarantine on cardiovascular risk. European Journal of Clinical Nutrition 74: 852-55. [CrossRef] [PubMed]

Miranda, Dionisio. 1992. Buting Pinoy. Manila: Logos Publications.

Moore, T. J., Melanie S. Hill, Pamela Ebstyne King, Rob Palkovitz, David C. Dollahite, and Loren D. Marks. 2018. Loving God, loving others: The sacred among American mainline protestant families. Marriage \& Family Review 54: 733-48.

Padilla, Estella. 2017. Ganda: Isang pagtinging kultural. In Ang maganda sa teolohiya. Quezon City: Claretian Communications Foundation Inc.

Pargament, Kenneth, Margaret Feuille, and Donna Burdzy. 2011. The Brief RCOPE: Current Psychometric Status of a Short Measure of Religious Coping. Religions 2: 51-76. [CrossRef]

Patinio, Ferdinand. 2020. More Pinoys Believe Faith 'Very Important' In Fighting Covid-19. Available online: https://www.pna.gov.ph/ articles/1108913 (accessed on 2 December 2021).

Pew Research Center. 2021. More Americans than People in Other Advanced Economies Say COVID-19 Has Strengthened Religious Faith. Available online: https:/ / www.pewforum.org/2021/01/27/more-americans-than-people-in-other-advanced-economiessay-covid-19-has-strengthened-religious-faith/ (accessed on 29 December 2021).

Philippine Statistics Authority. 2019. Philippines in Figures. Available online: https://psa.gov.ph/sites/default/files/PIF2019_revised. pdf (accessed on 26 December 2021).

Pope Paul VI. 1975. Evangelii Nuntiandi: Apostolic Exhortation of His Holiness Pope Paul VI to the Episcopate, to the Clergy and to All the Faithful of the Entire World, on Evangelization in the Modern World. Homebush: Society of St Paul.

Prazeres, Filipe, Lígia Passos, JoséAugusto Simões, Pedro Simões, Carlos Martins, and Andreia Teixeira. 2020. COVID-19-Related Fear and Anxiety: Spiritual-Religious Coping in Healthcare Workers in Portugal. International Journal of Environmental Research and Public Health 18: 220. [CrossRef] [PubMed]

Resurreccion, Ron. 2007. Malasakit, Pakikipagkapwa, at Kalinisang Loob: Mga Pundasyon ng Kagandahang Loob. Malay 19: 3. Available online: https: / / ejournals.ph/article.php?id=7899 (accessed on 18 June 2021). [CrossRef]

Rilveria, John Robert. 2018. The development of the Filipino coping strategies scale. Asia-Pacific Social Science Review 18: 111-26.

Saladino, Valeria, Davide Algeri, and Vincenzo Auriemma. 2020. The Psychological and Social Impact of Covid-19: New Perspectives of Well-Being. Frontiers in Psychology 11: 2550. [CrossRef]

Schieman, Scott, Alex Bierman, Laura Upenieks, and Christopher G. Ellison. 2017. Love Thy Self? How Belief in a Supportive God Shapes Self-Esteem. Religious Research Association 59: 293-318. [CrossRef]

Schillebeeckx, Edward. 1980. Jesus: An experiment in Christology. New York: The Seabury Press.

Shepperd, James A., Gabrielle Pogge, Nikolette P. Lipsey, Wendi A. Miller, and Gregory D. Webster. 2019. Belief in a loving versus punitive God and behavior. Journal of Research on Adolescence 29: 390-401. [CrossRef]

Stroope, Samuel, Scott Draper, and Andrew Whitehead. 2013. Images of a Loving God and Sense of Meaning in Life. Social Indicators Research 111: 25-44. [CrossRef] 
Synod of Bishops. 1974. Third Ordinary General Assembly of the Synod of Bishops. Available online: http://secretariat.synod.va/ content/synod/en/synodal_assemblies/1974--third-ordinary-general-assembly--evangelization-in-the-mod.html (accessed on 1 December 2021).

Tan, Michael. 2007. “Ganda” by Michael Tan: Pinoy kasi. Available online: http://michaeltanpinoykasi.blogspot.com/2007/05/ganda. html (accessed on 17 June 2021).

Thomas, Justin, and Mariapaola Barbato. 2020. Positive Religious Coping and Mental Health among Christians and Muslims in Response to the COVID-19 Pandemic. Religions 11: 498. Available online: https://www.mdpi.com/2077-1444/11/10/498 (accessed on 19 August 2021). [CrossRef]

UNFPA Philippines. 2020. Young People. Available online: https://philippines.unfpa.org/en/node/15309 (accessed on 26 December 2021).

WHO Coronavirus (COVID-19) Dashboard. 2021. Available online: https:/ / covid19.who.int/ (accessed on 26 December 2021).

Zahl, Bonnie, and Nicholas Gibson. 2012. God representations, attachment to God, and satisfaction with life: A comparison of doctrinal and experiential representations of God in Christian young adults. The International Journal for the Psychology of Religion 22: 216-30. [CrossRef]

Zarrouq, Btissame, Nivine Abbas, Jaouad El Hilaly, Achraf El Asri, Samira Abbouyi, Majid Omari, Hicham Malki, Samira Bouazza, Salma Ghofrane Moutawakkil, Karima Halim, and et al. 2021. An investigation of the association between religious coping, fatigue, anxiety and depressive symptoms during the COVID-19 pandemic in Morocco: A web-based cross-sectional survey. BMC Psychiatry 21: 264. Available online: https://bmcpsychiatry.biomedcentral.com/articles/10.1186/s12888-021-03271-6 (accessed on 17 August 2021). [CrossRef] [PubMed] 